\title{
ANALISIS SEGMEN PASAR DAN PERILAKU NASABAH BANK SYARIAH: KAJIAN HUKUM ISLAM TERHADAP PRODUK HSBC AMANAH INDONESIA
}

\author{
Mansur Chadi Mursid \& Rr. Kathrin Irviana*
}

\begin{abstract}
Market Segment Analysis of Islamic Banking and Customer Behavior: Islamic Law Study against HSBC Amanah Indonesia Products. The purpose of this research is for identifying market segment and customer behavior toward Islamic banking and its marketing implications in all regions of DKI Jakarta. The analytical tools applied are analysis of cluster, factor and descriptive. The result of this research for segmentation aspect showed the characteristics and size of each market segment of Islamic banks. The market segment consists of syariah loyalist, floating mass and conventional loyalist. From this research, floating mass segment is the most potential segment due to its market size compared to syariah loyalist and conventional loyalist segments.
\end{abstract}

Keywords: market segmentation, consumer behavior, Islamic banking

\begin{abstract}
Analisis Segmen Pasar dan Perilaku Nasabah Bank Syariah: Kajian Hukum Islam terhadap Produk HSBC Amanah Indonesia. Tujuan dari penelitian ini adalah untuk mengidentifikasi segmen pasar dan perilaku pelanggan terhadap Perbankan Syariah dan implikasi pemasaran di seluruh wilayah DKI Jakarta. Alat-alat analisis yang digunakan adalah analisis cluster, faktor dan deskriptif. Hasil penelitian yang terkait dengan aspek segmentasi menunjukkan bahwa karakteristik dan ukuran masing-masing pasar membedakan bank syariah. Segmen pasar terdiri atassyariah loyalis, massa mengambang dan loyalis konvensional. Hasil penelitian ini menunjukkan bahwa segmen masa mengambang merupakan segmen paling potensial karena sebagai pasar terbesar dibandingkan dengan segmen loyalis dan konvensional.
\end{abstract}

Kata Kunci: segmen pasar, perilaku nasabah, bank Islam

Naskah diterima: 7 Februari 2012, direvisi: 18 Mei 2012, disetujui: 24 Mei 2012.

*Jurusan Syariah STAIN Pekalongan. Jl. Kusumabangsa, No. 9, Pekalongan, Jawa Tengah, 51114. E-mail: Mansur.chadi@gmail.com 


\section{Pendahuluan}

Sejarah berdirinya perbankan syariah karena dua alasan utama, yaitu adanya pandangan bahwa bunga (interest) pada bank konvensional hukumnya haram dan dari aspek ekonomi di mana penyerahan risiko usaha terhadap salah satu pihak dinilai melanggar norma keadilan. Hadirnya bank syariah di Indonesia didorong oleh keinginan masyarakat Indonesia (terutama masyarakat Islam) yang berpandangan bahwa bunga bank adalah riba. Sejak 1992, industri perbankan syariah di Indonesia mulai berkembang cukup pesat sampai dengan saat ini, bahkan diperkirakan akan terus berkembang pesat di masa yang akan datang. Bank Indonesia ${ }^{1}$ memperkirakan bahwa jumlah aset perbankan syariah dibandingkan seluruh jumlah perbankan nasional mencapai 9,10\% pada tahun 2011.

Hal ini didukung pula oleh terbitnya Undang-Undang No. 10 tahun 1998 tentang Perbankan yang secara eksplisit memperbolehkan operasional bank berdasarkan prinsip syariah baik bagi Bank Umum maupun Bank Perkreditan Rakyat. Era inilah yang menandai dimulainya sistem perbankan ganda (dual banking system) dalam sistem hukum perbankan di Indonesia, yaitu sistem perbankan konvensional dan sistem perbankan syariah. Bahkan bank umum konvensional diperkenankan untuk membuka layanan syariah melalui Islamic window dengan terlebih dahulu membentuk Unit Usaha Syariah (UUS).

Pertumbuhan ekonomi provinsi DKI Jakarta (termasuk Banten) yang tinggi dan menjadi penyumbang pertumbuhan ekonomi terbesar secara nasional, yaitu sebesar 26,4\% pada tahun 2007. Berdasarkan data yang dikeluarkan oleh Bappeda DKI Jakarta ${ }^{2}$, kinerja perbankan di wilayah provinsi DKI Jakarta pada 2007 juga menunjukkan peningkatan. Penghimpunan Dana Pihak Ketiga (DPK) mencapai Rp 725,7 trilyun atau meningkat sebesar 13,6\% dibandingkan tahun sebelumnya. Komposisi DPK terbesar dalam bentuk deposito, yaitu sebesar Rp 401,8 trilyun atau 55,4\% dari keseluruhan DPK. Nilai kredit yang disalurkan juga mengalami peningkatan sebesar $26,4 \%$ dengan nilai kredit yang telah disalurkan sebesar Rp 503,8 trilyun. Oleh karena itu, DKI Jakarta merupakan provinsi yang memiliki pangsa pasar perbankan terbesar di Indonesia sehingga dibutuhkan informasi berbasis pasar yang dapat digunakan sebagai pertimbangan dalam merancang strategi pengembangan sistem perbankan syariah yang tepat dan disesuaikan dengan kebutuhan masyarakat.

1 Bank Indonesia, Statistik Perbankan Syariah 2004, dalam http://www.bi.go.id, diakses tanggal 25 Februari 2008.

${ }^{2}$ Bappeda DKI Jakarta, Data Perbankan Provinsi DKI Jakarta (termasuk Banten) 2008, dalam http://www.jakarta.go.id, diakses tanggal 26 Februari 2008. 
Studi ini bermaksud menjawab beberapa pertanyaan penelitian sebagai berikut: Bagaimana segmen pasar perbankan syariah di wilayah provinsi DKI Jakarta? Bagaimana preferensi dan sumber informasi nasabah tentang bank syariah? Apakah faktor-faktor yang memengaruhi responden dalam memilih bank syariah? Bagaimana formulasi strategi pemasaran bagi industri perbankan syariah sesuai dengan segmentasi pasar dan perilaku nasabah terhadap bankbank syariah yang akan/telah ber-operasi di wilayah penelitian? Bagaimana pandangan hukum Islam terhadap produk HSBC Amanah Indonesia?

\section{Review Kepustakaan}

Riba secara bahasa bermakna ziyâdah yang berarti tambahan. Dalam pengertian lain, secara linguistik, riba juga berarti tumbuh dan membesar ${ }^{3}$. M. Syafi'i Antonio menyatakan bahwa menurut istilah teknis, riba berarti pengambilan tambahan dari pokok atau modal secara batil. Riba bukan hanya merupakan persoalan Islam saja, tetapi berbagai kalangan di luar Islam pun memandang serius persoalan ini. ${ }^{4}$

Beberapa studi terdahulu yang mendasari penelitian ini adalah Karim Business Consulting, melakukan penelitian tentang segmentasi dan perilaku nasabah terhadap bank syariah di Indonesia dengan pendekatan value graphic map dan service orientation. Studi ini menghasilkan tiga segmentasi pasar perbankan syariah, yaitu syariah loyalist, floating mass, dan conventional loyalist. Pembagian segmen pasar dilakukan dengan pendekatan kualitatif (focus group discussion dan in depth interview). ${ }^{5}$

A. Wijaya melakukan analisis segmen pasar dan perilaku nasabah terhadap bank syariah di wilayah Daerah Istimewa (DI) Yogyakarta dengan membagi segmen pasar perbankan syariah menjadi syariah loyalist, floating more syariah, floating less syariah dan conventional loyalist dengan analisis deskriptif, analisis faktor, dan analisis klaster. Hasil penelitian menunjukkan bahwa segmen floating more syariah merupakan pasar sasaran yang paling potensial di wilayah DI Yogyakarta dibandingkan segmen-segmen lainnya. ${ }^{6}$

${ }^{3}$ A. Saeed, Islamic Banking and Interest: A Study of prohibition of Riba and its Contemporary Interpretation, (Leiden: EJ Brill, 1996).

${ }^{4}$ M. Syafi'i Antonio, Bank Syariah: Wacana Ulama dan Cendekiawan, (Jakarta: STEI Tazkia, 1999).

${ }^{5}$ Karim Business Consulting, Islamic Banking Consumer Behaviour in Indonesia: A Qualitative Approach, (Jakarta: KBC, 2005).

${ }^{6}$ Wijaya, A. Analisis Segmen Pasar dan Perilaku Nasabah terhadap Bank Syariah di Wilayah Yogyakarta dan Implikasi Pemasarannya, Tesis tidak diterbitkan, (Bogor: Manajemen dan Bisnis Institut Pertanian Bogor, 2006). 
Harahap (2003) melakukan penelitian untuk melihat potensi pendirian BNI Syariah di Kota Bogor dengan mellihat respons masyarakat terhadap beberapa perbankan syariah. Pengambilan sampel dilakukan dengan teknik cluster sampling dan non-probability sampling yaitu dengan teknik quota sampling.

BI dan LP IPB melakukan penelitian tentang potensi, sikap dan perilaku masyarakat terhadap bank syariah di Jawa Barat dengan survai yang dilakukan dengan menggunakan metode regresi logistic dan analisis deskriptif. Penelitian ini mengatakan bahwa profesionalisme dan jenis pelayanan bank syariah masih berada di bawah bank konvensional dan masyarakat berpenghasilan menengah ke bawah lebih meminati bank syariah karena sistem "jemput bola" yang diterapkan oleh bank syariah rendah. ${ }^{7}$

BI dan CBR Universitas Andalas melakukan penelitian mengenai identifikasi faktor penentu keputusan konsumen dalam memilih jasa perbankan antara bank syariah dengan bank konvensional. Penelitian dilakukan di empat wilayah Sumatera Barat dengan kriteria bahwa pada masing-masing wilayah telah beroperasi kedua tipe bank (bank syariah dan bank konvensional) dengan menggunakan analisis statistik deskriptif (tabulasi silang, grafik, rata-rata, dan frekuensi), analisis faktor, dan crosstab analysis. Hasil studi ini memberikan informasi tentang pertimbangan responden yang paling dominan di dalam memilih jasa bank syariah, yaitu faktor keyakinan bahwa bunga bank bertentangan dengan agama. ${ }^{8}$

Hendrawan (2004) melakukan penelitian di Tebet tentang perilaku nasabah tabungan bank setelah dikeluarkannya fatwa MUI mengenai bunga bank. Penelitian dilakukan dengan metode survai dan metode purposive sampling (hanya nasabah muslim dari seluruh populasi). Responden sebesar 100 orang dan pengambilan sampling dilakukan dengan metode convenience sampling. Data yang diperoleh diolah dengan analisis deskriptif, tabulasi silang, uji chi square, regresi logistic, dan metode thurstone. Studi ini mendapatkan bahwa perilaku nasabah Muslim pasca fatwa MUI adalah menyesuaikan pola pikirnya dengan pengetahuan yang baru.

\section{Metodologi}

Penelitian dilakukan dengan metode deskriptif dan kuantitatif melalui

${ }^{7}$ Bank Indonesia dan LP Institut Pertanian Bogor, Potensi, Sikap dan Perilaku Masyarakat terhadap Bank Syariah di wilayah Jawa Barat, (Bogor: Lembaga Penelitian IPB, 2000).

${ }^{8}$ Bank Indonesia dan CBR Universitas Andalas, Identifikasi Faktor Penentu Keputusan Konsumen dalam Memilih Jasa Perbankan antara Bank Syariah dengan Bank Konvensional di wilayah Sumatera Barat, (Jakarta: Bank Indonesia, 2006). 
pendekatan survei. Survei dilakukan dengan melakukan wawancara langsung (face to face interview). Metode pengumpulan data responden dilakukan dengan menggunakan sampel tak berpeluang (non probability sampling). Teknik yang dipilih dalam penelitian ini adalah menggunakan teknik sampel kemudahan (convenience sampling).

Jenis data yang digunakan dalam penelitian ini adalah data primer (pengamatan dan penelitian langsung di lapangan, wawancara dan pengisian kuesioner oleh responden), dan data sekunder (literatur-literatur buku, jurnal dan penelitian-penelitian sebelumnya) baik yang bersifat kualitatif maupun kuantitatif.

Penentuan jumlah sampel dari populasi yang diinginkan ${ }^{9}$ :

$$
\mathrm{n}_{\mathrm{o}}=\frac{\mathrm{Z}^{2} \times \mathrm{p}(1-\mathrm{p})}{\mathrm{e}^{2}}
$$

Setelah $\mathrm{n}_{\mathrm{o}}$ diketahui maka selanjutnya dilakukan koreksi, sehingga menjadi:

$$
\mathrm{n}=\frac{\mathrm{n}_{\mathrm{o}}}{1+\left(\mathrm{n}_{\mathrm{o}}-1\right) / \mathrm{N}}
$$

di mana:

$\mathrm{Z}=$ tingkat kepercayaan dugaan $(1-\alpha)$

$\mathrm{p}=$ proporsi sampel

$\mathrm{e}=$ kesalahan dugaan (sampling error)

$\mathrm{n}=$ jumlah sampel setelah koreksi populasi terhingga

$\mathrm{n}_{\mathrm{o}}=$ jumlah sampel sebelum koreksi populasi terhingga

$\mathrm{N}=$ jumlah populasi

Berdasarkan pendekatan tersebut, maka dalam menentukan jumlah sampel yang akan digunakan dalam penelitian ini digunakan ketentuan sebagai berikut:

$\mathrm{N}=$ populasi penduduk provinsi DKI Jakarta 8.468.471 orang

$\mathrm{Z}=90 \%$ (tingkat kepercayaan 90\%)

$\mathrm{p}=50 \%$ (proporsi sampel 50\%)

e $=7,5 \%$ (sampling error $7,5 \%$ )

Perhitungan :

$$
\begin{aligned}
& \mathrm{n}_{\mathrm{o}}=\frac{1,645^{2} \times 0,5(1-0,5)}{0,075^{2}} \\
& \mathrm{n}_{\mathrm{o}}=120,26778
\end{aligned}
$$

\footnotetext{
${ }^{9}$ B. Suharjo, Sampling Technique, (Jakarta: Mars School of Marketing \& Research, 2006).
} 
Setelah $\mathrm{n}_{\mathrm{o}}$ diketahui sebesar 120,26778 maka selanjutnya dilakukan koreksi populasi terhingga dengan jumlah populasi (N) sebanyak 8.468.471 orang.

$$
\begin{aligned}
& \mathrm{n}=\frac{120,26778}{1+(120,26778-1) / 8.468 .471} \\
& \mathrm{n}=120,26608 \\
& \mathrm{n}=120 \text { (pembulatan) }
\end{aligned}
$$

Berdasarkan perhitungan, maka ukuran sampel yang digunakan sebanyak 120 responden, terdiri atas 13 responden berasal dari Jakarta Pusat (11\%), 20 responden berasal dari Jakarta Utara (16,8\%), 23 responden berasal dari Jakarta Barat (19,3\%), 27 responden berasal dari Jakarta Selatan (22,3\%) dan 37 responden berasal dari Jakarta Timur (30,6\%).

Sebelum penelitian dilakukan, maka terlebih dahulu dilakukan penelitian awal untuk menguji instrumen pengumpulan data dengan uji validitas dan uji reliabilitas. Setelah mendapatkan hasil yang valid dan reliabel melalui uji validitas dan uji reliabilitas, kemudian dilakukan penelitian lanjutan dengan menggunakan tiga jenis analisis yaitu analisis klaster (cluster analysis), analisis faktor (factor analysis) dan analisis deskriptif (descriptive analysis).

\section{Diskusi dan Analisis}

Uji validitas dan reliabilitas pada penelitian awal ini, dilakukan dengan teknik Cronbach's Alpha dengan alat bantu SPSS 11.5. Hasil pengujian ini menunjukkan bahwa kuesioner yang dibuat telah memenuhi standar yang valid dan reliabel pada taraf kepercayaan 95\%.

Pertama, demografi responden. Responden dianalisis berdasarkan karakteristik demografi. Hasil yang didapat dari analisis ini, yaitu mayoritas responden sudah berusia di atas 40 tahun (28,33\%), status keluarga belum menikah (29,17\%), beragama Islam (82,50\%), jenis kelamin perempuan (53,33\%), pekerjaan pegawai swasta (49,17\%), memiliki tingkat pendidikan formal sampai dengan S1 atau setara (66,67\%), kedudukan sosial masyarakat biasa (94,17\%), rata-rata jumlah pengeluaran (per orang) per bulan kurang dari Rp 1.000.000,- (41,67\%) dan responden dengan 5,01\%-10,00\% dari penghasilan ditabung (30,83\%).

Kedua, segmentasi pasar perbankan syariah. Analisis segmentasi pasar perbankan syariah menggunakan alat analisis multivariate (K-Means Cluster 
Analysis) dengan menggunakan data survei dari 120 responden di wilayah DKI Jakarta. Analisis ini menghasilkan klaster 1 yang merupakan segmen syariah loyalist dengan jumlah 32 orang, klaster 2 merupakan segmen floating mass dengan jumlah 49 orang. Sementara segmen conventional loyalist sudah diidentifikasi sebelum analisis ini dilakukan yang terdiri atas responden yang tidak tertarik dengan bank syariah dengan jumlah 39 orang.

Ketiga, preferensi dan sumber informasi nasabah tentang bank syariah. Segmen pasar syariah loyalist memperoleh sumber informasi mayoritas dari teman atau keluarga sebesar 20,2\%. Sedangkan, segmen pasar floating mass mendapatkan informasi dari melihat iklan di media cetak sebesar 16,9\% dan segmen pasar conventional loyalist mendapatkan informasi mengenai bank syariah secara dominan dari dua jenis sumber informasi yang berbeda yaitu melihat iklan di TV dan melihat langsung kantor cabang bank syariah masingmasing sebesar 18,9\%.

Penelitian ini juga menganalisis lebih lanjut tentang preferensi tentang Bank Syariah yaitu mayoritas responden memilih menggunakan Bahasa Indonesia sebagai nama ideal produk bank syariah agar dapat lebih mudah dimengerti, daerah perkantoran dan pemukiman sebagai lokasi ideal bank syariah, karyawan bank syariah sebaiknya Islam, jilbab sebaiknya digunakan oleh karyawan wanita di bank syariah.

Keempat, perilaku nasabah berdasarkan faktor-faktor dalam memilih bank. Analisis faktor dilakukan dengan uji keiser-meyer olkin (KMO), measures of adequacy, dan bartlett test of sphericity. Menurut Simamora ${ }^{10}$, analisis faktor layak untuk dilanjutkan apabila nilai KMO uji berkisar mempunyai nilai indeks tinggi yakni berkisar antara 0,5 sampai 1,0. Hasil uji KMO menunjukkan bahwa nilai yang didapatkan adalah 0,855 yang berarti bahwa sampel sudah mencukupi dan dinyatakan baik berdasarkan pedoman rekomendasi dari Sharma (1994). Setelah dilakukan uji Bartlett's Test, tampak bahwa nilai chi-square adalah 852,856 dengan df 153 dan signifikansi 0,000 yang berarti bahwa matriks korelasi yang diuji bukan merupakan matriks identitas sehingga matriks korelasi dinyatakan layak untuk dilakukan analisis faktor.

Tahapan selanjutnya dilakukan pengujian secara parsial terhadap setiap variabel dan didapatkan hasil dari tabel anti-image matrices bahwa nilai MSA (measures of sampling adequacy) dari setiap variabel $(0,5)$ sehingga semua variabel bisa diproses lebih lanjut. Tahap selanjutnya yang dilakukan adalah mengetahui banyaknya faktor yang akan terbentuk yang didentifikasi dari nilai

${ }^{10}$ B. Simamora, Analisis Multivariate Pemasaran, (Jakarta: PT. Gramedia Pustaka Utama, 2005). 
eigenvalues (1). Dengan menggunakan metode ekstraksi principal component analysis, maka terbentuk empat faktor yang diekstrak dari 18 variabel yang ditandai dengan nilai eigenvalues.

Setelah diketahui terdapat empat kelompok faktor, maka dilakukan prosedur varimax rotation untuk mengidentifikasi hubungan antara faktor dan variabel individual sehingga matriks menjadi lebih sederhana dan mudah diinterpretasikan. Berdasarkan hasil out-put rotated component matrix, maka dilakukan interprestasi terhadap faktor yang telah mengelompok dan penamaan terhadap empat kelompok faktor dengan menggunakan pendekatan surrogate variable yakni pemilihan nama berdasarkan nilai factor loading tertinggi yaitu: Faktor 1 (tampilan fisik), faktor 2 (jaringan ATM), faktor 3 (keragaman produk), faktor 4 (tingkat bagi hasi).

Dari hasil analisis faktor (dengan uji KMO) dan analisis deskriptif yang telah dilakukan dalam melihat perilaku nasabah yang berkaitan dengan faktor-faktor yang memengaruhi untuk memilih suatu bank, tampak tidak terdapat perbedaan yang signifikan. Responden menganggap bahwa jaringan kantor dan ATM yang luas, keragaman produk, reputasi dan image suatu bank, kecepatan dan efisiensi pelayanan yang baik, tingkat bagi hasil yang menarik, waktu operasi yang sesuai maupun keramah-tamahan karyawan bank merupakan faktor-faktor dominan yang memengaruhi mereka dalam memilih suatu bank. Kemudian dilakukan analisis lebih lanjut berkaitan dengan alasan responden berminat terhadap produk dan jasa bank syariah berdasarkan kategori nasabah.

Kelima, nasabah bank syariah. Alasan responden berminat terhadap produk dan jasa bank syariah bila dibandingkan dengan bank konvensional adalah karena adanya aspek syariahnya yaitu sesuai dengan syariat Islam (55,0\%) dan faktor tidak adanya riba sehingga halal dalam pengelolaan dana (27,0\%).

Keenam, nasabah bank syariah dan bank konvensional. Alasan responden berminat terhadap produk dan jasa bank syariah bila dibandingkan dengan bank konvensional adalah karena bank syariah tidak mengandung unsur riba atau halal dalam pengelolaan dananya (49\%) dan sesuai dengan syariat agama Islam (26\%).

Ketujuh, nasabah bank konvensional. Alasan responden berminat terhadap produk dan jasa bank syariah karena sesuai dengan ajaran agama Islam (30,0\%), adanya aspek syariahnya yaitu faktor tidak adanya riba dalam pengelolaan dana (28,0\%). Alasan utama mengenai tetap dipertahankannya rekening di bank konvensional bagi nasabah yang mempunyai rekening di bank syariah dan bank konvensional secara bersamaan yaitu kurang lengkapnya fasilitas bank syariah (27,0\%) sehingga menyebabkan nasabah tetap menggu- 
nakan bank konvensional. Alasan utama nasabah bank konvensional tidak berminat terhadap produk dan jasa bank syariah yaitu karena minimnya informasi yang didapat mengenai bank syariah sementara nasabah bank konvensional sangat mudah untuk mendapatkan informasi lengkap mengenai bank konvensional (37,0 \%).

Dari hasil analisis yang dilakukan, yaitu analisis klaster dan analisis faktor, tampak bahwa antar segmen yang dihasilkan yaitu segmen syariah loyalist, floating mass dan conventional loyalist tidak terdapat perbedaan yang signifikan terhadap faktor-faktor yang memengaruhi dalam memilih suatu bank, yang membedakan hanyalah urutan prioritasnya. Faktor-faktor yang menjadi pertimbangan bagi responden dalam memilih suatu bank adalah jaringan kantor dan ATM yang luas, kecepatan dan efisiensi pelayanan, keramah-tamahan karyawan bank serta reputasi dan image bank itu sendiri. Jaringan kantor dan ATM yang luas menduduki peringkat tertinggi sedangkan bila dilihat dari aspek demografi, responden memilih perkantoran dan pemukiman sebagai lokasi ideal bank syariah. Hal ini dimungkinkan karena mayoritas responden memiliki jenis pekerjaan sebagai pegawai swasta dan wiraswasta.

Selain itu, uji analisis KMO menghasilkan tampilan fisik bank baik internal maupun eksternal, jaringan kantor dan ATM yang luas, reputasi dan image suatu bank, keragaman produk, waktu operasi bank serta tingkat bagi hasil yang menarik sebagai faktor-faktor yang memengaruhi responden dalam memilih suatu bank. Waktu operasi bank juga merupakan hal yang penting bagi pegawai swasta bila dikaitkan dengan waktu bekerja mereka yang terbatas dan sudah ditentukan. Kebutuhan akan keragaman produk muncul dari latar belakang responden yang mayoritas tamat $\mathrm{S}$ - atau setara sehingga cenderung memiliki kebutuhan akan variasi produk bank.

Apabila analisis ini dikaitkan dengan analisis minat responden terhadap bank syariah, tampak bahwa responden masih tetap mempertahankan rekening di bank konvensional ataupun tidak berminat sama sekali terhadap bank syariah disebabkan faktor-faktor kurang lengkapnya fasilitas bank syariah dibandingkan bank konvensional, kurangnya informasi mengenai bank syariah sehingga mereka menganggap belum perlu bank syariah ataupun tidak ada perbedaan antara bank syariah dan bank konvensional. Belum tersosialisasinya sumbersumber informasi bank syariah merupakan salah satu kendala bagi responden dalam memenuhi kebutuhannya akan informasi tentang bank syariah. Bagi responden yang berminat terhadap bank syariah disebabkan aspek syariat Islam dan tidak riba, hal ini dimungkinkan karena responden didominasi oleh responden beragama Islam. Dari semua analisis yang dilakukan, penelitian ini 
memiliki keterbatasan yaitu tidak dilakukannya identifikasi terhadap hubungan antara faktor-faktor yang memengaruhi responden dalam memilih suatu bank. Hal ini dapat dilakukan dengan penelitian selanjutnya menggunakan crosstab analysis.

Kedelapan, formulasi strategi pemasaran. Pencapaian tujuan dan sasaran pemasaran bagi perbankan syariah dapat dicapai dengan menerapkan strategi pemasaran yang tepat dengan memperhatikan faktor-faktor yang memengaruhi dalam pemilihan suatu bank. Pembahasan tentang formulasi strategi pemasaran bagi perbankan syariah di wilayah propinsi DKI Jakarta didasarkan pada analisis yang telah dilakukan. Dari hasil penelitian ini telah menunjukkan bahwa segmen pasar perbankan syariah di wilayah DKI Jakarta terdiri atassyariah loyalist, floating mass dan conventional loyalist yang memiliki karakteristik maupun besar segmen yang berbeda-beda. Untuk itu, maka bank syariah perlu menggunakan strategi pemasaran yang difokuskan kepada segmenting, targeting dan positioning (STP) didasarkan atas perbedaan karakteristik dan besar segmen yang ada.

Setelah karakteristik dan besar setiap segmen pasar diketahui, maka formulasi strategi pemasaran perbankan syariah hendaknya dimulai dengan pemahaman segmen yang ada tersebut. Setelah itu, perbankan syariah dapat merumuskan target market dengan mempertimbangkan potensi pasar serta kekuatan dan kelemahan yang dimiliki oleh bank syariah terkait dengan karakteristik nasabah yang hendak dijadikan target marketnya.

Berdasarkan potensi pasar dan besar segmen yang ada, maka segmen pasar floating mass merupakan potential target market di wilayah propinsi DKI Jakarta. Apabila perbankan syariah ingin menjadikan segmen ini sebagai target marketnya, maka perbankan syariah harus dapat menentukan positioning yang tepat dengan menjaga keseimbangan antara atribut syariah dengan atribut perbankan, bahkan akan lebih baik lagi bila dapat meningkatkan kualitas dan kuantitas atribut syariahnya sehingga segmen floating mass tidak ragu-ragu untuk menentukan mana prioritas atribut yang dipilihnya. Hal ini dapat dilakukan seperti dengan menjaga secara konsisten penerapan prinsip syariah dalam praktik perbankan syariah sehingga dapat menciptakan rasa aman dan jaminan bebas dari riba.

Berdasarkan hasil analisis terhadap faktor-faktor yang dipertimbangkan dalam memilih bank syariah, maka bank syariah sebaiknya memberikan kemudahan aksesibilitas lokasi jaringan kantor dan ATM yang bisa dilakukan dengan pengembangan jaringan kantor kas (office channeling) dan penambahan jumlah mesin ATM ataupun melalui kerjasama dengan beberapa jaringan ATM (seperti penggunaan ATM Bersama) di lokasi perkantoran dan pemukiman. 
Kecepatan dan efisiensi pelayanan dapat diberikan melalui karyawan bank yang cakap dan terlatih. Hal ini dapat dilakukan dengan memberikan pelatihanpelatihan yang memadai terhadap karyawan bank syariah sehingga tingkat pelayanan yang diberikan oleh bank syariah dapat bersaing dengan bank konvensional.

Begitu pula dengan keramah-tamahan pun perlu dijaga agar nasabah merasa nyaman bila berinteraksi dengan bank syariah. Reputasi dan image bank syariah sebagai bank yang mengedepankan prinsip-prinsip syariah harus dipertahankan sehingga tidak tercipta opini bahwa bank syariah sama saja dengan bank konvensional. Produk perbankan yang dikembangkan hendaknya bervariasi sehingga memudahkan nasabah dalam memilih produk sesuai dengan kebutuhannya. Tingkat bagi hasil simpanan yang menarik dan juga tingkat bagi hasil pembiayaan yang rendah dapat membuat nasabah menjadi lebih tertarik dengan bank syariah dibandingkan bank konvensional. Fasilitas yang lengkap juga perlu ditingkatkan dan setidaknya dapat sejajar dengan bank konvensional.

Selain itu diperlukan juga perbaikan sumber-sumber informasi untuk menyosialisasikan perbankan syariah. Perbankan syariah seharusnya mampu memberikan fasilitas dan pelayanan yang dapat bersaing dengan perbankan konvensional. Jika perbankan syariah memiliki keunggulan dalam aksesibilitas, fasilitas, dan pelayanan dibandingkan dengan perbankan konvensional, maka segmen floating mass merupakan target market yang paling tepat. Sedangkan apabila ingin mengembangkan segmen syariah loyalist, maka perbankan syariah harus mampu meningkatkan, menerapkan maupun mengkomunikasikan seluruh atribut potensial syariahnya. Pertimbangan utama responden yang berasal dari segmen syariah loyalist memilih menggunakan bank syariah adalah karena sesuai dengan syariat Islam dan tidak riba (halal). Untuk menjaga loyalitas responden, bank syariah harus mampu menjaga dengan konsisten aspek-aspek yang berhubungan dengan pertimbangan tersebut. Bank syariah harus konsisten menjalankan ekonomi Islam dalam praktik perbankan syariah agar rasa aman yang diharapkan oleh responden dapat terjaga dan terus meningkat.

Strategi pemasaran yang harus dikembangkan adalah dengan mengomunikasikan dengan baik keunggulan aspek syariah terutama aspek yang berhubungan dengan syariat Islam seperti produk yang sesuai dengan akad. Walaupun responden bank syariah sudah dalam tahap penggunaan, namun bank syariah harus meningkatkan loyalitas responden terhadap penggunaan bank syariah dengan menjaga harapan-harapan responden, termasuk menjaga 
motivasi responden dalam menggunakan bank syariah karena sistem bagi hasil, untuk menjalankan syariat agama dan karena tidak menggunakan sistem bunga. Hal ini mengindikasikan bahwa responden bank syariah lebih mengedepankan aspek fanatisme sebagai muslim bukan karena faktor ekonomi.

Tantangan bagi bank syariah adalah harus menonjolkan aspek-aspek yang logis dan real bagi responden agar penggunaan bank syariah lebih karena faktor ekonomi Islam yang ideal. Selain itu, jumlah segmen pasar ini memang relatif kecil dibandingkan segmen pasar yang lain, namun memiliki keunggulan yakni tidak terlalu sensitif dengan pricing produk. Apabila perbankan syariah mampu menunjukkan konsistensinya terhadap aspek syariah, maka akan membuat nasabah menjadi loyal. Keberhasilan perumusan dan penerapan formulasi strategi pemasaran sangat ditentukan oleh kemampuan untuk mempelajari karakteristik dan besar segmen pasar, sehingga penentuan target market dan positioning dapat dirumuskan dengan tepat sehingga akhirnya dapat membuat perbankan syariah khususnya di wilayah DKI Jakarta mampu bersaing dengan perbankan konvensional lainnya.

\section{Kajian Hukum Islam terhadap Produk HSBC Amanah Indonesia}

Amanah Savings Account-iB memberikan pilihan untuk melakukan transaksi dengan mudah dan kemungkinan untuk mendapatkan bonus. Tabungan berdasarkan prinsip wadî'ah (titipan terjamin) yang bermanfaat sebagai rekening utama untuk mengelola dan meningkatkan simpanan. Wadî’ah menurut bahasa artinya sesuatu barang yang dititipkan bukan pada pemiliknya untuk dijaga ${ }^{11}$. Wadî’ah mengikuti wazan fa'îlah dari lafaz wada'a. Menurut syarak, arti dari wadî’ah adalah menitipkan sesuatu benda kepada orang lain serta menjaga dan memeliharanya dengan itikad yang baik.

Asal hukumnya sunah apabila orang yang dititipi bisa menjaga titipan tersebut. Jika tidak ada yang sanggup selain orang tersebut maka menjadi wajib titipan pada orang tersebut, dan tidak merusak manfaat barang titipan serta ada tempat yang layak untuk menjaga. Wadî’ah dapat menjadi haram hukumya apabila merusak dan membuka pintu kehancuran barang titipan. Menjadi makruh jika bisa menjaga tetapi tidak menjamin keselamatan barang tersebut. Wadî'ah menjadi batal karena tiga alasan: (1) Salah satu dari orang yang dititipi atau orang yang menitipi barang keadaannya menjadi gila atau mati; (2) Orang yang dititipi mengembalikan barang titipan tersebut; (3) Hancurnya barang titip-

11 Himâm Nashir al-Dîn, Fath al-Naqib fî Tarjamah Fath al-Qarîb, (Kudus: Maktabah wa Mathba'ah Menara Kudus, t.th.), h. 375. 
an dengan sendirinya.

Orang yang menerima titipan tidak menanggung jika rusak (kecuali karena keteledorannya) bila disebabkan oleh keadaan berikut: (1) Menitipkan barang kepada orang lain lagi tanpa ijin pemilik barang tersebut; (2) Memindahkan barang titipan baik dari kampung atau desa ke tempat yang lebih rendah jaminan keselamatannya; (3) Pergi begitu saja.

Apabila terjadi pertikaian antara kedua belah pihak disebabkan dua keadaan, yaitu: (1) Orang yang dititipi merasa sudah menyerahkan barang titipan, maka dibenarkan orang yang dititipi; (2) Orang yang menitipkan barang belum menerima barang titipannya, maka yang dibenarkan yang menitipkan barang.

Amanah Term Investment-iB ideal untuk pribadi atau korporasi yang menginginkan kemungkinan mendapatkan keuntungan dan mementingkan kepatuhan terhadap prinsip Syariah. Produk ini diterapkan berdasarkan prinsip syariah, yaitu mudhârabah (kerjasama investasi). Pengertian mudhârabah adalah akad kerja sama antara dua pihak, di mana pihak pertama menyediakan seluruh modal dan pihak lain menjadi pengelola. ${ }^{12}$ Keuntungan dibagi menurut kesepakatan yang dituangkan dalam kontrak. Apabila rugi maka akan ditanggung pemilik modal selama kerugian itu bukan akibat dari kelalaian si pengelola. Apabila kerugian diakibatkan kelalaian pengelola, maka si pengelolalah yang bertanggung jawab.

Mudhârabah muthlaqah merupakan kerja sama antara pihak pertama dan pihak lain yang cakupannya lebih luas. Maksudnya tidak dibatasi oleh waktu, spesifikasi usaha dan daerah bisnis. Mudhârabah muqayyadah merupakan kebalikan dari mudhârabah muthlaqah di mana pihak lain dibatasi oleh waktu spesifikasi usaha dan daerah bisnis ${ }^{13}$. Dalam dunia perbankan mudhârabah biasanya diaplikasikan pada produk pembiayaan atau pendanaan seperti, pembiayaan modal kerja. Dana untuk kegiatan mudhârabah diambil dari simpanan tabungan berjangka seperti tabungan haji atau tabungan kurban. Dana juga dapat dilakukan dari deposito biasa dan deposito spesial yang dititipkan nasabah untuk usaha tertentu.

12 Anny Ratnawati dan Mansur Chadi Mursid, "Potensi dan Strategi Pengembangan Bank Syariah di Indonesia: Kajian Produk Syariah dari Segi Fiqih Mu'amalat", Jurnal Hukum Islam, Volume 9, Nomor 2, Desember 2011, h. 255.

13 Anny Ratnawati dan Mansur Chadi Mursid, "Potensi dan Strategi Pengembangan Bank Syariah di Indonesia", h. 255. 


\section{Penutup}

Terdapat tiga segmen pasar perbankan syariah di wilayah DKI Jakarta, yaitu segmen syariah loyalist, segmen floating mass, dan segmen conventional loyalist. Segmen syariah loyalist dominan berada di wilayah Jakarta Timur dan Jakarta Selatan, segmen floating mass berada di wilayah Jakarta Timur dan segmen conventional loyalist berada di wilayah Jakarta Barat. Selain itu, segmen floating mass merupakan target pasar yang paling potensial di wilayah provinsi DKI Jakarta karena memiliki pangsa pasar terbesar bila dibandingkan dengan segmen syariah loyalist ataupun segmen conventional loyalist. Walaupun demikian, masyarakat beragama Islam masih merupakan target pasar utama bagi bank syariah karena jumlah segmen floating mass secara dominan diperoleh dari responden beragama Islam dan didominasi oleh jenis pekerjaan pegawai swasta dan wiraswasta.

Berdasarkan analisis klaster dan analisis faktor, dihasilkan bahwa semua segmen tidak memiliki perbedaan yang signifikan terhadap faktor-faktor yang memengaruhi dalam memilih suatu bank, yang membedakan hanyalah urutan prioritasnya. Faktor-faktor yang memengaruhi responden dalam memilih suatu bank adalah jaringan kantor dan ATM yang luas, kecepatan dan efisiensi pelayanan, keramah-tamahan karyawan bank serta reputasi dan image bank itu sendiri. Jaringan kantor dan ATM yang luas menduduki peringkat tertinggi. Sedangkan bila dilihat dari aspek demografi, responden lebih memilih perkantoran dan pemukiman sebagai lokasi ideal bank syariah. Hal ini dimungkinkan karena mayoritas responden memiliki jenis pekerjaan sebagai pegawai swasta dan wiraswasta.

Uji analisis KMO menghasilkan tampilan fisik bank baik internal maupun eksternal, jaringan kantor dan ATM yang luas, reputasi, dan image suatu bank, keragaman produk, waktu operasi bank serta tingkat bagi hasil yang menarik sebagai faktor-faktor yang memengaruhi responden dalam memilih suatu bank. Waktu operasi bank juga merupakan hal yang penting bagi pegawai swasta bila dikaitkan dengan waktu bekerja mereka yang terbatas dan sudah ditentukan. Kebutuhan akan keragaman produk muncul dari latar belakang responden yang mayoritas tamat S-1 atau setara sehingga cenderung memiliki kebutuhan akan variasi produk bank. []

\section{Pustaka Acuan}

Antonio, M. Syafi'i, Bank Syariah: Wacana Ulama dan Cendekiawan, Jakarta: STEI Tazkia, 1999.

Bank Indonesia dan CBR Universitas Andalas, Identifikasi Faktor Penentu Kepu- 
tusan Konsumen dalam Memilih Jasa Perbankan antara Bank Syariah dengan Bank Konvensional di wilayah Sumatera Barat, Jakarta: Bank Indonesia, 2006.

Bank Indonesia dan LP Institut Pertanian Bogor, Potensi, Sikap dan Perilaku Masyarakat terhadap Bank Syariah di wilayah Jawa Barat. Bogor: Lembaga Penelitian IPB, 2000.

Bank Indonesia dan Pusat Penelitian Kajian Pembangunan Lembaga Penelitian Universitas Diponegoro Semarang, Penelitian Potensi, Preferensi dan Perilaku Masyarakat terhadap Bank Syariah di Wilayah Jawa Tengah dan Daerah Istimewa Yogyakarta, Jakarta: Bank Indonesia, 2000.

Bank Indonesia, Statistik Perbankan Syariah 2004, dalam http:/www.bi.go.id, diakses pada 25 Februari 2008.

Bappeda DKI Jakarta, Data Perbankan Provinsi DKI Jakarta (termasuk Banten), dalam http://www.jakarta.go.id, diakses tanggal 26 Februari 2008.

Direktorat Penelitian dan Pengaturan Perbankan Bank Indonesia, Potensi, Preferensi dan Perilaku Masyarakat terhadap Bank Syariah di Pulau Jawa, Jakarta: Bank Indonesia, 2000.

Direktorat Perbankan Syariah Bank Indonesia, Statistik Perbankan Syariah 2008, dalam http://www.bi.go.id, diakses pada 25 Febtuari 2008.

Karim Business Consulting, Islamic Banking Consumer Behaviour in Indonesia: A Qualitative Approach. Jakarta: KBC, 2005.

Nashîr al-Dîn, Himâm, Fath an-Naqib fî Tarjamah Fath al-Qarîb, Kudus: Maktabah wa Mathba'ah Menara Kudus, t.th.

Priyatno, D., Mandiri Belajar SPSS untuk Analisis Data dan Uji Statistik, Yogyakarta: MediaKom, 2008.

Ratnawati, Anny, dan Mursid, Mansur Chadi, Potensi dan Strategi Pengembangan Bank Syariah di Indonesia: Kajian Produk Syariah dari Segi Fiqih Mu'amalat, Jurnal Hukum Islam, Volume 9, Nomor 2, Desember 2011.

Saeed, A., Islamic Banking and Interest: A Study of prohibition of Riba and its Contemporary Interpretation, Leiden: EJ Brill, 1996.

Sharma, S., Applied Multivariate Techniques. Jakarta: Penerbit Erlangga, 1994.

Simamora, B., Analisis Multivariate Pemasaran, Jakarta: Penerbit PT Gramedia Pustaka Utama, 2005.

Suharjo, B., Sampling Technique, Jakarta: Mars School of Marketing \& Research, 2006.

Suku Dinas Kependudukan dan Catatan Sipil DKI Jakarta, Jumlah Penduduk Provinsi DKI Jakarta 2008, dalam http://www.jakarta.go.id, diakses pada 20 Januari 2008. 
Undang-Undang No. 10 Tahun 1998 tentang Perbankan, Jakarta: Bank Indonesia, 2000.

Wijaya, A., Analisis Segmen Pasar dan Perilaku Nasabah terhadap Bank Syariah di Wilayah Yogyakarta dan Implikasi Pemasarannya, Tesis tidak diterbitkan, Bogor: Manajemen dan Bisnis Institut Pertanian Bogor, 2006. 